\title{
Art and Memory as Reconciliation Tool? Re-Thinking Reconciliation Strategies in the Western Balkans
}

An Introduction

\author{
Maja Savić-Bojanić \\ Assistant professor, Department of Political Science and International \\ Relations, Sarajevo School of Science and Technology, Sarajevo, \\ Bosnia \& Herzegovina \\ maja.savic@ssst.edu.ba \\ Ilir Kalemaj \\ Associate professor, Department of Political Science and International \\ Relations, University of New York, Tirana, Albania \\ ikalemaj@unyt.edu.al
}

\begin{abstract}
The violent demise of Yugoslavia and the bloody period that marked most of the 199os in this region have sparked academic interest in the peacebuilding and reconciliation initiatives which emerged after the conflict. Scholarly literature on the subject went in the directions of transitional justice, social psychology and socio-political approaches. However, an unexplored alley of scholarly interest remains in the role of the arts in these processes. By examining the role of arts and memory creation, this introductory article posits these against the background of a problematic reconciliation process in post-conflict areas of the Western Balkans as its core topic. Situated in a post-Yugoslav geographic space, where ethnic conflicts still hinder development, people rest much on the interpretation of the meaning of lived experiences, and the role of images, arts, myths and stories, which are used to either create or dissemble the path to peace between the many ethnic communities that inhabit this area of Europe. The use of several overlapping, yet differently interpreted themes relating to lived experiences and history shows them as symbolic transitional justice policies. They broadly deal with how such knowledges are interpreted through lived moments, such as cinema, museums and public monuments.
\end{abstract}




\section{Keywords}

arts - reconciliation - memory - transitional justice - post-Yugoslav states

Post-Yugoslav history has initiated a new era of socio-political relations in the region, but what has continuously sparked academic interest in this part of Europe is an often-disputed process of peacebuilding and reconciliation. This has resulted in several distinct, yet interlinked methodologies for analyzing post-conflict spaces. These can be classified into two groups: the transitional justice line and the inter-group understanding approach. Some of the main contributions regarding transitional justice measures have been those of the school of retributivists, who insist in prosecuting the mass perpetrators of human rights abuses (Drumbl 2007), or give a particular focus to lustration as prime example of addressing the past (Kalemaj 2021). On the other hand, we have the restorationists, who depend on forms of truth-telling (Teitel, 2002; Wiebelhaus-Brahm 2010), as well as reparative justice that seeks to repair damage done (Muddell \& Hawkins 2018). The transitional justice approach takes different forms in post-genocide and post-conflict societies on the one hand and post-communist societies on the other. But in the former Yugoslav space and the subsequently emerging republics, these two are strongly intertwined.

The inter-group understanding approach, on the other hand, focuses on constructive communication between different ethnic groups in order to help groups relate and agree on a common framework of understanding that goes both ways. Also, this is an inclusive rather than exclusionary approach. This opens up the potential for reconciliation, as various authors have argued (i.e., Nikolić-Ristanović 2017). While both schools are heavily linked to empirical evidence, they mostly disregard or scarcely mention the role of arts, culture and past conflict, despite growing evidence which speaks of the links between them. And indeed, art and culture on one hand and conflict, on the other, form a complex nexus in which the understanding of all of three elements is necessary in order to examine how the former impacts the latter, and also, more importantly, to what degree artistic expression influences conflict and post-conflict societies and their culture.

To depart on this complex mission, it is inevitable that one first differentiates between culture and art, as the former forms a much broader concept in which artistic expression is just one line of embedment. Culture, more 
broadly, is linked to identity and hence is capable of shaping the individual meanings of the world around us. It is within these individual interpretations of understanding "us" and "self" that we arrive at conflict - this is where conflict intersects with culture. However, different cultures do not necessarily enter into conflict with one another (LeBaron 2001), but it is the perceived barriers, often in a primordialist sense, that spark conflict between the cultures and identities which they create. This complex relationship between culture and conflict generates the cultural content of group identity. Bar$\mathrm{Tal}$ (2003) states that conflicting groups shape their own perceptions of and about the conflict, thus positioning the "self" as victims against the "other". As a result emerge different forms of expression about the conflict, and this is where the role of art comes in. Conflict generates different cultural products, such as songs, films or oral traditions that generate further violence during conflict. Alternatively, however, such artistic expressions take communities along different paths after the conflict, and although they may fuel negative emotional responses such as anger or remorse, they also mark the beginning of an individual reconciliatory process. However, for a society-wide process of reconciliation to occur, several other factors need to be operative, such as addressing injustices and inequalities, recognizing the suffering of others and creating non-threatening spaces for healing. According to scholars such as Hayner (2001) and Cohen and Yalen (2015), reconciliation entails rebuilding of relationships that are not based on past conflicts, but require novel forms of interactions which emerge in a post-conflict setting. One of these is art and memory creation.

This special issue focuses on the role of arts and memory in the reconciliation process in post-conflict areas of the Western Balkans. Situated in a post-Yugoslav geographic space, the articles embedded in this volume are of qualitative design, resting much on the interpretation of the meaning of lived experiences, the role of images, arts, myths and stories which are used to either create or dissemble the path to peace between the many ethnic communities which inhabit this area of Europe. The focus on war-remembering monuments, museums, cinema and other art forms as a way to aid in reconciling the people of former Yugoslavia and foster cooperation through comprehension via a combination of explanatory, analytical and comparative methods as well as syncretic approaches, helps add an often-overlooked dimension in the present literature and fills an important empirical gap. This special volume is also comparative in nature, since the selected case studies and narratives used by authors cover almost all the post-Yugoslav space, including Croatia, Bosnia and Herzegovina, Kosovo and Serbia. The preference for qualitative and comparative approaches is linked to the fact that all authors, except one, are scholars 
of the region and from the region, two facts which have considerably eased the rapprochement of traditional vernacular narratives to a broader academic audience of non-native origin.

Given all this, the special issue and the articles imbedded in it have a dual aim. Firstly, we want to offer a critical analysis of most popular artistic trends and expressions explicitly and implicitly employed in fostering reconciliation in the Western Balkans, focusing on four key forms: art as a lived experience, monuments as a (re)invented form of ethnic trust and de-construction of national myths. This somehow offers a different perspective from what French historian Pierre Nora has meant by his term lieux de mémoire and the role they have played in the commemoration processes, or his further discussion of how new emblems, anthems, mottoes or institutions, as well as people, make possible the creation of many of the means through which "memories are perpetuated" (Nora, 1996: xvii). National identities in former Yugoslavia have often been rebuilt in the aftermath of communism through process of rememorization, which in turn have required extensive state-building efforts from nationalist political elites (Kalemaj 2008).

The second goal of this special issue is to create a basis for a new research agenda and offer a comparative foundation for investigating the relationship between varying art forms and trusting relationship formation with the "other" as key to social cohesion in post-conflict spaces. By giving space to the above themes, we trust that we will open three news paths for future research on the topic of arts and reconciliation in post-conflict societies of former Yugoslavia: the first one consists of positing museums, cinema, monuments and how they are lived, interpreted and re-interpreted. This dynamic is quintessential for political themes in everyday political (and also public) narratives and as a tool for framing particular historical events. The second avenue involves capturing how monuments are used as a catalyst for strengthening anti-fascist feeling. The Yugoslav demise was a particularly disconcerting process with a broad social impact, but we know little about the impact of old monuments in contemporary rebuilding of trust between former "comrades" and "compatriots" and new, wartime "enemies". Lastly, we propose a shift in the current paradigm whereby myths are understood as tools of territorialization of ethnic oral tradition. Instead, we propose a shift to the explanation of the potential of myths as common and shared, with the aim of emphasizing its reconciliatory potential in ethnically mixed and conflict-prone areas. Finally, our focus is on case-studies from four countries of former Yugoslavia, since they allow for a better understanding of how art impacts propensities for reconciliation. Since art allows individuals to understand and explain their nation's violent past, the changes that occur within impacted (ethnic) communities reflect on the power of artistic expression to contribute to inter-ethnic reconciliation. Thus, 
we are able to reach conclusions about the conciliatory effects of specific arts in given contexts.

Given the above, this introductory article and the contributions in this special issue answer an array of different queries: how do we reconcile divided societies through the arts in the aftermath of a conflict? What is transferred through different forms of artistic expression that so well leads to increased inter-group understanding? What are the ways in which arts and their varying forms transform the negative image of the "other" and the social norms established during a conflict? Can we re-build trust among neighbours if international reconciliation efforts and the state approach to interpreting art prevail in a post-conflict setting? Can reconceptualization of public spaces aid the process? Can visual artistic expression help deal with war crimes? Is there enough will to do all of the above?

In approaching the above questions, this article draws on the literature on transitional justice and case-studies from across post-conflict contexts, as well as broader literature on the role of the arts in post-violent settings. It seeks to build upon the existing research which, although scarce and confined to specific cases such as Lebanon, Sudan and Canada, offers a solid basis for understanding how art and memory may (or may not) work as reconciliatory tools. The article is structured as follows: we first discuss the meaning of symbolic transitional justice and link it to the contextual basis of the special issue in order to arrive at a short discussion of the research paths which we aim to disentangle through the contributions presented here. Second, we discuss the effects of art and artistic expression in post-conflict spaces, drawing attention to some of the most recent regional examples which testify to the reconciliatory role of art and memory in post-violent settings. By acknowledging the dual nature of artistic absorption and its misappropriation by political leaders in the ethnically divided states of former Yugoslavia, we also draw attention to the emerging attitudes and behaviours and new acknowledgment of past events which, in the forms of art or places of memory, play a reconciliatory role. In the third part, we focus on the critical analysis of artistic dialogue and the bottom-up approach of individual understanding of art and memory which slowly leads to the reconceptualization of a violent past. Lastly, we provide an overview of the works embedded in this special issue and highlight its contribution to wider literature on the subject.

A contested and vague yet imperative process of reconciliation in postconflict spaces has, explicitly or implicitly, shaped transitional justice policies, 
which by their very nature seek to establish new political attitudes towards the "other" in a manner that is conducive to trust-building. The inevitability of reconciliation requires substantial state involvement in the process, but what remains unknown are the individual-level effects that such policies generate. Although we might think that formal state-run reconciliation policies are rational, they often do not suffice in the process of altering the established animosities and transforming them into an established relationship of trust (Cohen and Yalen 2015). This is especially difficult if trauma and loss marked the relationship between two or more groups for a significant period of time. Thus, despite groups' participation in reconciliation projects and policies that are both externally and internally driven, the lack of public understanding of the effect of "soft" reconciliation that occurs through the absorption of artistic content offered in the process of reconciling with the "other" is rather jarring insomuch as these "lived experiences" remain integral in the process of imagining, forming and confirming personal and collective identities (Pruitt 2011; Clay 2006; Connell \& Gibson 2003). This is why arts often represent a "go-to" peacebuilding instrument. Lederach (2005) accentuates the potential of the art as a creative endeavor that drives the process of peacebuilding. He argues that professionalization, technique and conflict management cast a shadow on the potential of the creative process that art brings to deep-rooted conflict areas. And indeed, contemporary works of art in post-conflict societies have often formed an inextricable link with violence: artists, through their particular expressions, have challenged perpetrators and have, consciously, used memorialization to increase the attention of all groups involved regarding past conflict, trauma and remembrance - but with little scholarly attention to the importance of the frameworks that they present in peacebuilding. The gap that exists is, thus, precisely the one between arts in post-conflict contexts and expectations for the developing of a middle-ground peacebuilding perspective - one which is driven by common understandings of the creative in the reconciliation process.

Recent literature on arts and culture in the reconciliation processes includes context-specific examinations, such as Naidu-Silverman's (2015) work on the topic in Asia, but also Canada (Robinson and Martin, 2016) and Bosnia and Herzegovina (Zelizer, 2003). More specific literature also includes works on music and art and conflict transformation (Slachmuijlder 2005; Urbain 2008; Bergh and Sloboda 2010) and theater (Cohen et al. 2011; Slachmuijlder 2012; Rush and Simic 2014). What needs accentuating is the fact that much of the existing scholarly work has been put forward by art practitioners working in the performing arts (music and theater), which results in approaches that are practice-based and focused on specific art forms. This has also resulted in 
different terminology from art and memory work, art and conflict-transformation and art and peacebuilding, but without realization that each term puts a different emphasis on ways in which art is framed and the effects that it creates. This forms a disjuncture between how practioners define their work versus how official policies define the arts and embed them into reconciliation, the latter definition ending up being imposed and standing at odds with the initial value that was imagined by the artist. Thus, we remain fully cognizant of the transformative and participatory capacity of art and its non-threatening ways of attracting people to observe each other's but also individual and personal perspectives, but in this special issue we seek to go beyond these cleavages and examine the arts-based reconciliation in the Western Balkans, acknowledging the five focal ways in which arts contribute to peacebuilding, ${ }^{1}$ but focusing specifically on the perspective of "art as remembering" and "art as dialogue". Considering the ethnically diverse context in which the authors posit their works, we trust that these two perspectives are best suited to framing the examined particularities of each work here.

Lastly, we wish to point to the specificities of the examined context. Released from the straightjacket of violent wars and even genocide, the interplay of arts and reconciliation remains a puzzling observation in the post-Yugoslav geographic space, often so because artistic expression has a dual potential - it fuels violence, but also facilitates reconciliation. Alternatively, acknowledging a deeply politicized reconciliation process, it is clear that any form of peacebuilding is often rejected by communities and perceived as problematic and redundant. Hence, a major question remains: how to engage the latter in rebuilding a peaceful sociality through cultural activities? In conflictridden and ethnically divided societies, understanding that art may (and does) form an integral part of violent struggle, the opposite trend - that of art that emerges as a counterforce to conflict - must also be observed and understood more broadly as a mnemonic process which elucidates and feeds the political and societal changes in a conflict's aftermath.

Despite varying artistic meaning of cinema, museums and cultural monuments as bearers of collective memory, the contexts in which their role becomes crucial in a post-conflict environment of a shared past and "new", independent history remain the same - those of generators of "new knowledge" about "the other" or "others", depending on how community entities are perceived. The "mental" barriers that post-Yugoslav communities experience heavily lean on how they interpret their shared Yugoslav past and the subsequent wars of

1 Art as (i) healing, (ii) remembering, (iii) pursuit for truth, (iv) dialogue, (v) embedding peaceful values (Fairey, 2017). 
secession, simultaneously disregarding this "healing" aspect of arts and memory that we perceive as aspects that serve as a unifying force and do not allow (wo)man to be just an island on their own. Considering this, we posit arts and artistic memory as the core themes and examine their understudied role in the process of reconciliation in post-conflict communities of former Yugoslav states. The use of several overlapping, yet differently interpreted themes relating to lived experiences and history as seen through myths broadly deals with how such knowledges are interpreted through live moments, such as cinema and museums. This approach is essential as it allows us to observe a plethora of artistic forms and their observation and understanding, and, although they are utterly different in terms of the reconciliatory message conveyed, they all allow for observing their own impact on different forms of identity formation and remembering in relations to "others".

In the aftermath of the dramatic and violence-ridden years which marked the Yugoslav demise, the new states which emerged following the bloody divorce found themselves in a position in which the demand for the punishment of perpetrators and ethnic divisions became a post-conflict norm. Denial, intimidation and guilt threatened the new democratically oriented societies. Yet democracy could not reconcile the position that these new norms of blame and guilt imposed on the general public. Countries such as Bosnia and Herzegovina were so deeply divided along ethnic lines that wartime perpetrators remained in power in one part of the country, and hence were in a position to threaten the very survival of the state. According to O'Donnell and Schmitter (1986), such instances may develop into "omnipresent fear", whereby "the other" remains the enemy, consequently harming the process of transitional justice.

Although transitional justice policies appear in a variety of forms, from the punishment of perpetrators to truth revelation procedures, symbolic transitional justice, which institutes either material or symbolic reparation for victims, remains scarcely approached in studies which refer to reconciliation avenues in the countries of former Yugoslavia. A by-product of institutionalized ethnic divisions, symbolic transitional justice, which acknowledges victims collectively through spaces of memory, museums, films and musical performances, has escaped the policy aspect; yet it remains important on the individual and community levels across these states. This is where the role of art and its expression emerge. Evidence suggests that symbolic transitional policies focus on educating the general public and re-focusing their attention on 
universal human rights, rather than on "otherness" and punishment as a form of establishing justice. As such, they also tend to be heavily disputed. Stories from Lebanon (Loveluck 2018) and Peru (Pereda 2018) recount how symbolic transitional justice that appears in the form of museums and places of memory may easily turn into controversial projects of reconciliation because of individual perceptions and understanding of such places and of the artistic components that they entail. This is precisely the complexity of post-conflict societies: individuals' understanding and absorption of artistic expression varies according to political views and ideologies, as well as contextual understanding of a post-conflict space and the level of violence to which a particular group (and its members) was exposed.

Nevertheless, heterogeneous perceptions of art in the process of reconciliation are also essential, and may be even more important to discuss. In the aftermath of violence, individuals on all sides have probably experienced loss and trauma which is difficult to verbalize and make sense of. In this situation, we agree with the postulates which suggest that symbolic justice, shaped as art, helps in acknowledging the past and influences emerging attitudes and behaviors (Jelín 2007; Hite 2011; Hite, Collins, \& Joignant 2013). We also accept that, through imagery and symbolism, artistic expression may also stir up negative emotions and slow the process of reconciling with the "enemy" or the "past", but eventually these emotions will become similar as communities learn of the same experiences from each other. Hence, just as the wider scholarly literature suggests (Fortier 2008; Daly and Sarkin 2007; Cohen and Yalen 2015), art is capable of allowing individuals "to participate in reconciliation processes, access their emotions and begin their individual healing processes" (NaiduSilverman 2015). Art, be its creative expressions music, dance or oral traditions, or monumental places of memory, has the power to recreate historical pasts. Through individual absorption, understanding and meaning-making of artistic forms, both victims and perpetrators overcome barriers, which transform into "intergenerational transmission of historical memory" (Hamber 2006). The aesthetic processes which are played out and displayed provide an ally for new communication - individuals stop focusing solely on violent historical events, and ascribe to them new meanings as experiences and places of meeting, dialogue and re-building trust and relationships. This is the ally which exposes two ways in which arts may be used to reconcile.

Initially, artistic expressions which are immersed in memorialization often serve the purpose of remembering the fallen victims and averting the process of forgetting human rights violations, such as genocide. Such "memory art" represents a way to witness, document and collect evidence of past atrocities, but also of commemorating those lost and their living families. Yet, its most 
powerful expression lies in creating a counter-narrative to the official history or to perpetrators' interpretations of history. This is the major concern - can such artistic forms effectively commemorate the past and assure just treatment of perpetrators? The dilemma is especially valid in post-conflict spaces of post-Yugoslav states where the perspective of "art as remembering" remains the predominant form of use of the arts in the peacebuilding process. Alternatively, the perspective of "art as dialogue" represents a process of creating dialogue which acknowledges multiple truths without forcing conflict resolution or mutual understanding. Rather, this is the artistic space where encounter and safe space play a role in bringing communities together and facing each other's encounter of truths. Such artistic projects rely on the dialogical power of the arts to (re)build empathy by exposing participants to others' sufferings and break existing stereotypes, especially among youth participants. Unlike the former, "memory art" model, "art as dialogue" initiatives focus on the process rather than on a mere installation which is prone to individual observations and may change very little in terms of understanding the "other". In fact, dialogical art is a process in which artistic expression and creation may join former belligerent groups in artistic collaborations. The ultimate aim is firstly that of trust-building, which then gives birth to the re-building of relationships.

Such understandings are easy to grasp, and this is why politicians in post-conflict settings often manipulate arts and places of artistic expression and memory-making in order to establish their positions and, during crucial times of elections and re-elections, use them to reaffirm their support among ethnic voters (Savić-Bojanić \& Repovac-Nikšić 2019) - a case in point in states such as Bosnia and Herzegovina, Kosovo and North Macedonia. For instance, in Bosnia and Herzegovina wartime memorials (1992-1995) frequently serve as sites from which domestic leaders address wider publics speaking of victims, suffering and heroes, notably during pre-election periods.

The same goes for Northern Macedonia, as well as for Kosovo, the difference in Kosovo's case being that the memorials are often erected to commemorate recent ethnic conflict and the war crimes of Milosevic's regime. Furthermore, Kosovo's Albanians and Kosovo's Serbs have different heroes, have erected different memorials and have forms of commemoration of events that often juxtapose with each other, or at least present different memories. Politicians of both camps help to create different narratives of nation-building, and often this precludes successful reconciliation. This is when oral traditions, religious symbolism and traditional artistic forms re-emerge in a way in which they become the dividing instruments in post-conflict spaces. 
On the other hand, site like the Childhood War Museum in Sarajevo create the opposite feeling, since this site of artistic expression and memory-making is impartial in its approach to war. It tells the stories of children who lived through the Sarajevo siege, and by taking the victim-centred approach, this Museum educates visitors on how to prevent future conflicts, activating emotional responses and shifting perceptions, especially those of young visitors who were not directly involved in wartime experience. It is in such places where the potential of art, as understood globally, has the power to persuade visitors and audiences to reconcile their salient considerations of conflict. Through the lived process of experiencing and seeing that "our children" suffered as much as "your children", a place of artistic expression becomes a venue of dialogue and active listening, if not understanding.

Also, in the difficult Kosovo-Serbia post-war relationship, attempts to bring in art as sort of transition bridge have begun, notwithstanding the difficulties, scepticism and obstacles from both sides. For example, cultural activists and artists from Kosovo that have used art as a way of addressing their wartime traumas have found some receptive ears among their Serbian counterparts, despite political opponency. A prime example of this is a festival called "Miredita, Dobar Dan" - meaning "good day" in both Serbian and Albanian that is "intended to showcase Kosovo culture to a Belgrade audience" (Selmani 2019). This festival faced some political obstacles and provocation days before it started, but it is a good example of a bottom-up, people-to-people initiative. This special issue explores this in further detail.

Artistic Dialogue and Trust-Building in Post-Yugoslav Space

Despite the obvious nexus between identity, culture and conflict, the arts represent a sort of soft power approach to peacebuilding and reconciliation efforts. Art comes as a last resort and as such it is often wrongly underrepresented in scholarly work on reconciliation initiatives and transitional justice. This is not surprising, since artists usually do not see themselves as primary actors in peacebuilding initiatives. However, this does not undermine the functionality of artistic work, in all its varying forms, in addressing conflict from a neutral, non-politicized angle. Seen from this perspective, art is still political and engages the different opposing parties, thus reducing tensions and conflictual situations as well as removing the subjects of contestation. Thus, what remains underexplored, not just in post-Yugoslav contexts but more broadly in post-conflict societies, is the effect of art in the process of memory creation and reconciliation. As Dagmar Reichert (2015) points out, there is a new 
enthusiasm in unravelling novel approaches to peacebuilding and addressing former violence. We find this in various forms of art, from museums and public spaces, to films, culture, newly written fiction or other forms of commemoration. Seen from this perspective, the post-Yugoslav states are just now emerging as an important context in which this relationship is worth considering.

Three decades after the dissolution of Yugoslavia and the experience of some of the bloodiest wars in Europe, there is still not a lasting feeling of "coming to terms". Yet, as all post-Yugoslav states have emerged from a conflict, there is incipient evidence that even in the most divided contexts, art, in all its forms, has provided a new form of communicating with each other through artistic creativity. The film and music industries in the former Yugoslav countries have been especially salient in transcending the initial feelings of animosity and have, more so than places of religious art and memorials, been able to act as venues of trust-building and active listening. According to David Bohm (2004) dialogue allows participants with opposing views to listen to each other and, in that process, suspend active prejudices and assumptions that had previously been formed. However, Bohm notes that this may result in frustrations; but a continuous process of dialogue and sharing eventually brings the participants together. Of course, dialogue cannot be consumed, and it is a process where we do not expect winners. This neutral process of dialogue is especially powerful if shaped as an art form, since art is lived and experienced through participating and sharing artistic expression, either through observation or directly through active participation. Most importantly, both the observers and the participants can influence the amount of absorption, a process which may seem like a slowing factor in a post-conflict setting where art is employed as a symbolic transitional justice policy or a means of non-aggressive communication. Hence, individuals are free to determine the extent to which they may go. However, the flexible and fluid nature of artistic observation and absorption allows for its unceasing effect in the process of reconciliation. This is highlighted in the example of an interreligious choir from Sarajevo, "Pontanima" (Bridge of the Souls), which brings together individuals from all ethnic groups who together perform religious songs from four major religious traditions. The choir brought together people from the two different entities, ${ }^{2}$ and through joint concerts, tours and socializing, all groups were able to begin a dialogue in a non-threatening space. Such participatory art emphasizes empathy since it allows all participants to identify with and learn about the other through artistic expression and participation.

2 Federation of Bosnia and Herzegovina and the Republic of Srpska. 
Artistic reconciliation, thus, allows all participants, both direct and indirect, to develop an awareness about the other - their experience, trauma and existing social issues. In such instances, new violence is prevented and animosity is transformed into awareness and lasting understanding. If this process takes place within a post-conflict society, the power of art, cultural festivals, interreligious performance groups and commemorative sites and events becomes the leading force conducive to cross-ethnic (cross-cultural) fluency and understanding. As museums, choirs, films and monumental spaces in post-Yugoslav states show, artistic activities, in whichever form, have shifted the dichotomy of "us versus them" and contributed to positive outlooks towards former enemies while building trust and respect. This is why such activities in the examined contexts are worth a closer look. As post-conflict societies, the post-Yugoslav states have all sought to establish new identities and understandings of self and others, while artistic expression has aided in the new approach to understanding the effects of the violence and division which have long persisted on their own in these states.

In bringing forward this special issue, the argument made is that in former Yugoslav states, as these are societies which emerged from a conflict, a significant leap forward in establishing alternative forms of transitional justice - which is expressed through symbols, memory and art - needs to be carefully scrutinized. Until very recently, reconciliation in the post-Yugoslav spaces has mainly taken on the form of reconstruction and peacebuilding strategies, all of which have been in the hands of domestic political elites or international actors. More recently, however, varying forms of art have provided an avenue for the common people to engage in these processes through their own stories, understandings and expressions of trauma and loss. From these emerged the new films, songs and places of memory which so successfully told the stories of "all" and not just "us" across the region. Such initiatives, which brought forward individual memories, were crucial in providing alternative narratives about past conflicts; they have, through metaphors and symbols, initiated regional stories about formerly silenced events that the bloody Yugoslav demise had left behind. What is currently surfacing is a slow, but steady, understanding of the fact that in a violent conflict everybody suffers. The recent Bosnian Oscar nominee Jasmila Žbanić tells a story of the Srebrenica Genocide in her multiple award-winning film "Quo Vadis, Aida?". The film received support from Serbian actors who, although facing numerous critiques in their home country for even acknowledging a film which speaks of a much-denied genocide in this small Bosnian town in 1995, show that art, in its various forms, provides spaces to address trauma, guilt and shame in a creative manner. The film has initiated numerous dialogues, but most importantly seems to be acting as an 
educational and dialogical tool which will raise awareness about the importance of addressing the ethnic violence of the past. Hence, although scarce, artistic expressions are emerging as essential tools of memorialization and reconciliation in former Yugoslav states. Very slowly they are allowing former belligerents to express their emotions about the past, ultimately paving the way for reflection and critical analysis of history from their own, "common people" angle.

Art \& Culture as a Source of Healing and Conflict Resolution in the Western Balkans

The selected sub-themes tackle the everyday experiences of common people; more broadly, they showcase the common perception of history, the shared past, the ethnic "other", myths and respective war crimes. This helps us to better understand how reconciliation takes place through art and memory and how shattered experiences can heal through a common understanding and a more holistic cultural frame. More specifically, the lived experiences which describe the symbolic behind museums, cinemas and monuments are essential in dealing with the interpreting and reinterpreting of political themes found in everyday political and public narratives in the form of specific tools for framing historical events. Moreover, such live artistic expressions uncover some of the emerging ways in which art is employed to reveal its reconciliatory character. Hence, the narrative on the role of gender in public spaces and cultural heritage helps in understanding how female partisan underrepresentation in Croatia's capital nurtures shame about the Yugoslav past, but also how monuments are used as a catalyst for strengthening the anti-fascist feeling. Furthermore, an analysis of war-crimes and cinema responds to the query of "how does non-nationalistic cinema shape reconciliation and promote peace?" Lastly, the research on Kosovo and the de-construction of myths leads to an understanding of territorialization and instrumentalization of ethnic oral traditions, or better yet of the potential of research to consider both as common and shared, with the aim of emphasizing its reconciliatory potential.

In this issue, we present four articles and their use of these overarching topics to explore their role in post-conflict reconciliation in a geographic region with a long-shared history. These articles have in common their quest to seek out and understand both past grievances and pathways towards present reconciliation, as well as to look into ways to build future consolidated multi-cultural societies. They do so by focusing on the cultural lenses and the potential that monuments, cinema and museums have in fostering trust and helping through 
a process of selective remembering and forgetting, overcoming the divisions of the past and helping societies heal and better communicate with each other.

To begin with Sanja Kajinić's article, the focus is on forgetting and remembering the socialist past through the monuments that commemorate the women partisans in Croatia. As the author notes, while there is an abundant literature in feminist studies that problematizes the lack of attention to the lives of women throughout the 2oth century in post-Yugoslav space, there is much less emphasis on the commemoration and remembering of women's role during WWII and in socialist Yugoslavia. Particularly in the 199os, after the fall of communism, the destruction of war monuments, including those dedicated to women that were partisans during wwII, became a common feature that defined the new cultural landscape. Although the study takes as its point of departure the Croatian case, which is analyzed in depth, the former Yugoslav landscape is analyzed in a comparative and systematic fashion that sheds light upon this otherwise missing point in the recent scholarship.

Rimante Jaugaite discusses the lack of will in dealing with war crimes in post-Yugoslav cinema. She argues that this often-overlooked topic is both timely and important, as cinema is proved elsewhere to be a method of reconciliation and trust-building in post-conflict societies. Film can cure the traumas associated with war and inter-ethnic or inter-religious conflicts, may help heal past wounds and forges long-lasting bonds among various communities. By analyzing different theories in the field and engaging the academic debate while also offering a lucid empirical analysis of various films across the former Yugoslav space, Jaugite's article brings fresh insights that help us not only to understand but also to reconceptualize the role of culture in bridging gaps and facilitating dialogue. This is also an effective way to deal with war crimes committed in the 1900 s among formerly co-existing republics and people of various ethnic or religious backgrounds.

Sarina Bakić, on the other hand, considers museum practices as one of the means of encouraging reconciliation among former belligerents. Bakić critically engages and analyzes the role that museums and museum practices have played in fostering dialogue and helping the pacification of traumatized societies, and in helping them achieve the necessary catharsis. Reconceptualizing museums as "new educational institutions", the author helps us understand their key role in nurturing cultural interaction and the exchange of ideas which in turn may lead to a different perception of one's identity and the way it relates to the "other".

Finally, a team of authors (Pavlović, Pudar-Draško and Lončar) examine the role, status and perceptions of the Serbian cultural heritage in Kosovo from both the Kosovo Albanian and the Serbian perspectives. The authors focus 
on two cases which attract particular resistance on each of the two sides: the unsuccessful 2015 Kosovo bid for UNESCO membership and the passing of legislation in the Kosovar parliament in 2012 that aimed to protect Serbian cultural heritage. They argue that both moments demonstrate how cultural heritage is primarily approached from the statehood perspective and used, additionally, to widen inter-ethnic distances divides. This is an important article that sheds more light on the discrepancies between the international peacebuilding efforts and internationally imposed legal framework, and dominant discourses in both Serbia and Kosovo that prevent any of these efforts from making a lasting change.

Finally, we firmly trust that this issue will broaden the understanding of the reconciliation process in the post-Yugoslav space and open up a new avenue for examining its path to peace, not only through dialogue and state policies, but also through non-traditional tools, such as arts and culture, that are accommodating to all audiences and groups, and which could promote inter-ethnic and inter-community peace.

\section{References}

Bar-Tal, D. 2003. "Collective Memory of Physical Violence: Its Contribution to the Culture of Violence," in E. Cairns and M.D. Roe (eds.), The Role of Memory in Ethnic Conflict (New York: Palgrave MacMillan).

Bergh, A., Sloboda, J., 2010. "Music and Art in Conflict Transformation: A Review," Music and Arts in Action 2.

Bohm, D. 2004. On Dialogue. 2nd edition (Routledge).

Clay, A. 20o6. "All I Need Is One Mic: Mobilizing Youth for Social Change in the PostCivil Rights Era," Social Justice 33 (2).

Cohen, C. and Yalen, L. 2015. Recasting Reconciliation through Culture and the Art: A Virtual Collection. Posting a Theoretical Framework. (The International Centre for Ethics, Justice and Public Life: Brandeis University).

Cohen, C. et al. (eds.). 2011. Acting Together I: Performance and the Creative Transformation of Conflict. Volume 1: Resistance and Reconciliation in Regions of Violence. (New Village Press).

Connell J. and Gibson, C. 2003. Sound Tracks: Popular Music, Identity and Place (London: Routledge).

Daly, E. and Sarkin, J. 2007. Reconciliation in Divided Societies: Finding Common Ground. (Philadelphia: University of Pennsylvania Press).

O'Donnell, G. and Schmitter, P. 1986. Transition from Authoritarian Rule: Tentative Conclusions. Baltimore: Johns Hopkins University Press. 
Drumbl, M. 2007. Atrocity, Punishment, and International Law. (New York: Cambridge University Press).

Fairey, T. 2017. "The Arts in Peace-building and Reconciliation: Mapping Practice," Art and Reconciliation Working Paper Series. Available at: https://www.artreconciliation. org/research-activities/publications/.

Fortier, A. 2008. "Culture and Conflict: Introduction," The Power of Culture Special-July 2008.

Hamber, B. 2006. "Flying Flags of Fear: The Role of Fear in the Process of Political Transition," Journal of Human Rights.

Hayner, P. 2001. Unspeakable Truths: Transitional Justice and the Challenge of Truth Commissions. (New York: Routledge).

Hite, K. 2011. Politics and the Art of Commemoration Memorials to struggle in Latin America and Spain. (New York: Routledge).

Jelín, E. 2007. "Public Memorialization in Perspective: Truth, Justice and Memory of Past Repression in the Southern Cone of South America," International Journal of Transitional Justice.

Kalemaj, I. 2008. "Recollection of Past Memories in Croatia: How Processes of Rememoration can build a New Identity," POLITIKON journal, Vol. 14, No. 2.

Kalemaj, I. 2021. "Transitional justice and democratic consolidation in post-communist Eastern Europe: Romania and Albania," Eastern Journal of European Studies, Volume 11, Issue 1, June 2021.

LeBaron, M. 2001. "Transforming Cultural Conflict in an Age of Complexity," in Berghof Handbook for Conflict Transformation. (Berlin: Berghof Research Center for Constructive Conflict Management).

Lederach, J.P. 2005. The Moral Imagination: The Art and Soul of Building Peace. (Oxford: Oxford University Press).

Loveluck, L. 2018. "Beirut civil war museum is haunting, but few Lebanese want to disturb the ghosts." Washington Post. Available at https://www.washingtonpost. com, accessed February 26, 2021.

Muddell, K. \& Sibley Hawkins. 2018. Gender and Transitional Justice: A Training Module Series. Module 3: Reparative Justice. (International Centre for Transitional Justice).

Naidu-Silverman, E. 2015. "The Contribution of Art and Culture in Peace and Reconciliation Processes in Asia." (Copenhagen: Centre for Culture and Development).

Nikolić-Ristanović, V. 2017. "Intergroup Communication and Reconciliation: Experiences from the Former Yugoslavia." Oxford Research Encyclopedias. Oxford: Oxford University Press.

Nora, Pierre and Lawrence D. Kritzman. 1996. Realms of Memory: The Construction of the French Past, Volume 1 - Conflicts and Divisions. Columbia University Press.

Nora, Pierre. 1996. "The Era of Commemoration," in Realms of Memory: Rethinking the French Past, Vol. III: Symbols. (New York: Columbia University Press). (PDF). 
O'Donnell, G. and Schmitter, P. 1986. Transitions from Authoritarian Rule: Tentative Conclusions About Uncertain Democracies. (Baltimore, MD: The Johns Hopkins University Press).

Pereda, David. 2018. "Fujimorismo en arremetida para intervenir el Lugar de la Memoria.” May 19. Available at: https://larepublica.pe. Accessed January, 2021.

Pruitt, L. J. 2011. "Music, youth and peacebuilding in Northern Ireland," Global Change, Peace and Security 23(2).

Reichert, D. 2015. “Art in Conflict”. Available at: https://www.artasfoundation.ch/assets/ downloads/2015_ReichertDagmar_ArtInPeaceBuildingWorkingWithParadoxes.pdf. Accessed January 2021.

Robinson, D., Martin, K., 2016. Arts of Engagement: Taking Action in and Beyond the Truth and Reconciliation Commission of Canada. (Wilfrid Laurier University Press).

Rush, P.D. and Simic, O. 2014. The Arts of Transitional Justice: Culture, Activism, and Memory after Atrocity. (Springer: Springer Series in Transitional Justice).

Savić-Bojanić, M. and Repovac-Nikšić, V. 2019. "' 'How We Understand Populism?': Popular Responses to Populist Politics in Bosnia and Herzegovina," Sociological Problems 2/2019.

Selmani, A. 2019. "Kosovo Artists Use Culture to Promote Justice and Peace," Balkan Transitional Justice, BIRN, Sept. 26. https://www.balkaninsight.com/2019/og/26/ kosovo-artists-use-culture-to-promote-justice-and-peace/.

Slachmuijlder, L., 2005. The Rhythm of Reconciliation: A Reflection on Drumming as a Contribution to Reconciliation Processes in Burundi and South Africa. (The International Center for Ethics, Justice, and Public Life at Brandeis University).

Slachmuijlder, L., 2012. Participatory Theatre for Conflict Transformation. Training Manual. (Search for Common Ground).

Teitel, Ruti G. 2002. Transitional Justice. (Oxford University Press).

Urbain, O., 2008. Music and Conflict Transformation: Harmonies and Dissonances in Geopolitics. (I. B. Taurus).

Wiebelhaus-Brahm, E. (2010), Truth Commissions and Transitional Societies: The Impact on Human Rights and Democracy. (New York: Routledge, 2010).

Zelizer, C., 2003. "The Role of Artistic Processes in Peace-building in BosniaHerzegovina," Peace and Conflict Studies 10. 